\title{
Agricultural Supply Chain Analysis During Supply Chain Disruptions: Case of Teff Commodity Supply Chain in Ethiopia in the era of COVID-19
}

\author{
Matiwos Ensermu Jaleta ${ }^{1}$ \\ ${ }^{1}$ Associate Professor of Department of Logistics and Supply Chain Management, College of Business and \\ Economics, School of Commerce, Addis Ababa University, Addis Ababa, Ethiopia \\ Correspondence: Matiwos Ensermu Jaleta, Department of Logistics and Supply Chain Management, College of \\ Business and Economics, School of Commerce, Addis Ababa University, Addis Ababa, Ethiopia.
}

Received: March 5, 2021 Accepted: May 30, 2021 Online Published: July 12, 2021

doi:10.5539/sar.v10n3p63 URL: https://doi.org/10.5539/sar.v10n3p63

\begin{abstract}
Current state agricultural supply chain analysis for essential commodities like Teff in Ethiopia is necessary to avoid supply chain disruption caused by events like COVID 19. The objective of this study is to assess the effect of COVID-19 on the agriculture and food sector. It has taken into account both qualitative and quantitative mixed approaches. The study has been conducted to analyze the resilient teff value chain across teff supply chain members from production to consumption by comparing two production areas in Ethiopia. Cross-sectional descriptive surveys at different stages of the supply chain are identified. Data collection has been made based on the purposive sampling technique. It has then, analyzed the data and reach on conclusion. The findings revealed that wealth was not accumulated by farmers to create a sustainable supply of Teff to the consumers which is not enough to respond to the demand gap created in the event of supply chain disruption. Teff value chain analysis also indicated that consumers have low price expectations of Teff regardless of its high price at the retail shop. Since March 2020 Due to COVID 19 prevalence in Ethiopia, lockdown that disrupts goods and people move from rural to urban has resulted in a sharp Teff price increase from an average of 4200 per Quintal to 5000 Birr per Quintal in just one month at the retail shop. This has significantly benefited downstream supply chain members like wholesalers and retailers by hoarding Teff supply to consumers until regulatory bodies took action on price hikes by retailers. Finally, recommendations have been forwarded among the others include: to enlarge subsidies for Ethiopian farmers to boost agricultural production, hedge farmers against price fluctuation and avail warehouses for stocking agricultural commodities to buffer against future uncertainties are the major ones that the government has to apply.
\end{abstract}

Keywords: Teff, supply chain analysis, value chain, agriculture

\section{Introduction}

Unexpected natural and human-made events like earthquakes, war, Coronavirus (COVID 19), are very likely to cause Supply Chain (SC) disruptions. Disruptions are considered as high-impact-low-frequent events in the supply chain (SC) that change the SC's structural design and significantly impact performance. The propagation of disruption through a SC and its associated impacts are the ripple effects. Beyond its immediate health effect, COVID 19 will have short to long-term effects on the Ethiopian economy as supply chain disruption is inevitable in the flow of goods and movement of people due to the government's lockdown strategy to contain the virus.

Evidence shows that there is a lack of uniformity in how countries are prepared for the epidemic and how to respond to it, (Mirgissa \& Yayehyirad, 2020). State actors are expected to make policy decisions on what to do if the virus is detected in a country, how to make available all necessary prevention resources for personal hygiene, improve surveillance and case detection, capacitate health facilities including human resources and provide mass education and awareness building at all levels (Mirgissa \& Yayehyirad, 2020). In the event of lack of buffer for uncertainty like COVID 19, agriculture commodity supply to the market can be disrupted and can cause shortage from the market side and hence sudden price increase on the available goods, especially essential food items, like Teff. For example, a study made in India showed that disruption in of food supply chains due to COVID-19 induced economic shut down and resulted in product availability falls by $10 \%$ for vegetables, fruits, and edible 
oils, but there is a minimal impact on their prices. On the farm-gate side, it is matched by a $20 \%$ fall in quantity arrivals of vegetables and fruits (Mahajan \& Tomar, 2020). Another study made by (Devereux et al., 2020; Flynn, 2020) stated that the supply chain affects not only producers, distributors, and consumers, but also food-processing plants that are labor-intensive. Production was reduced, suspended, or temporarily discontinued in many plants due to the workers who were found to be COVID-19 positive and who were reluctant to go to work, thinking that they would get sick at work, mostly in meat-processing food companies at the time of the outbreak. For these reasons, it was thought that the production capacity of pork facilities decreased by approximately $25 \%$ in late April.

According to (Sharma, Shishodia, Kamble, Gunasekaran \& Belhadi, 2020), the Agricultural Supply Chains (ASCs) are exposed to unprecedented risks following COVID-19. It is necessary to investigate the impact of risks and to create resilient ASC organizations. The findings reveal that supply risks, demand risks, financial risks, logistics and infrastructure risks, management and operational, policy and regulation, and biological and environmental risks have a significant impact on ASC depending upon the organizations' scope and scale. ASCs are defined as "the set of activities included in a "farm to fork" progression, including activities such as farming (i.e. cultivation of land for crop production), processing/ production, testing, packaging, warehousing, transportation, distribution and marketing' (Tsolakis et al., 2014). ASCs encompass the activities of supply management, production and process management, and demand management through a competitive distribution channel for satisfying the end consumers (Chandrasekaran and Raghuram, 2014).

As most of the developing and third world countries are heavily dependent on agriculture and agricultural imports, the ASCs in all these countries are exposed to unprecedented risks following COVID-19. Food and Agriculture Organization (FAO, 2020) reported that COVID-19 is affecting ASCs on two critical aspects viz. the demand and supply for food. Food supply and demand are directly related to the food security aspect; therefore, global food security is at risk (Siche, 2020). As SCs are labor-intensive for fisheries, meat products, and high-value crops, the effects of lockdown are taking a toll on the labor markets. The labor market shocks that arise from the movement restrictions on migrant laborers are affecting their ability to harvest, process, and the agricultural market produces. COVID-19 has had a significant impact on global food imports and exports. Along with the labor market issues, horticultural produce makes up a substantial part of the fresh food supply chains that have suffered heavily. Major ports worldwide are congested with reefer containers that cannot be shipped due to trade restrictions. Therefore, the shipments are being diverted to minor ports resulting in substantial revenue losses for the logistics providers (Hey, 2020).

COVID-19 has severely impacted all countries in the world and has caused several supply chain disruptions globally (Ivanov, 2020; Choi, 2020; Govindan, Mina \& Alavi, 2020). The current pandemic COVID-19 has inflicted an economic shock across the globe so drastic that it has been compared with the Great Depression of the 1930s as more than 170 countries will experience a negative per capita GDP growth (IMF, 2020).

On the other hand (Telukdarie, Munsamy, and Mohlala, 2020) stated, nowdays, the globe has been subjected to an unprecedented health challenge in the form of COVID-19, indiscriminately impacting the global economy, global supply chains, and nations.

Based on the study of (Aday, 2020), a pandemic is not a new event encountered in the history of humanity because mankind has faced various pandemics in history. The common point of pandemics is their serious negative effects on the global economy. Considering the food supply chain, one of the most important sectors of the economy, it has been seen that COVID-19 has an impact on the whole process from the field to the consumer. In the light of recent challenges in the food supply chain, there is now considerable concern about food production, processing, distribution, and demand. COVID-19 resulted in the movement restrictions of workers, changes in demand of consumers, closure of food production facilities, restricted food trade policies, and financial pressures in food supply chain. When the issue of how the COVID-19 pandemic affects consumers' food demand is examined, it is seen that the demand varies depending on the price of foodstuffs, income level of consumers, socio-demographic situation, consumption, and shopping preferences and time constraints. In addition, the number of the visits to food store and spending money on food per visit changed (Bakalis et al., 2020; Cranfield, 2020).

Some Recommendations to minimize the effect of Covid-19 is that the COVID-19 outbreak seriously threatens food safety, security, and nutrition. The economic chaos due to the pandemic threatens economic access and the physical availability of food. Disruptions and possible problems in marketing, logistics, and trade systems may restrict access to food in some places and times; therefore, hunger and malnutrition problems may appear (FAO, 2020g). A report from World Food Program showed that the number of people facing extreme hunger can 
increase to 265 million in 2020 as a result of COVID-19 (WFP, 2020a). Another study performed by Headey et al. (2020) indicated that COVID-19 leads to a $14.3 \%$ increase in the prevalence of wasting among children who are younger than 5 years old due to malnutrition or interruption of health and social protection in low and middle-income countries. Ethiopia's low-value chain position in the global supply chain i.e, low-value commodity exporters like coffee, and high-value finished goods importer like cars and computers, will make it hard to sustain supply chain disruption caused by COVID 19.

Therefore, the study attempts to analyze what are the supply chain cost and price of agricultural commodity like Teff across supply chain members from farmer to consumer during supply chain disruption in Ethiopia in the event of COVID 19?

\section{Methodology}

A cross-sectional survey at different stages of the supply chain is identified and descriptive analysis was made. Based on the popularity of the Teff production site, a purposive sampling technique was deployed. Accordingly, first, at upstream Teff supply chain, two farm sites in Oromia regional states of Ethiopia, where Teff is popularly known and produced by farmers were identified: namely: at 'Becho' district ( $55 \mathrm{~km}$ West of Addis Ababa) and 'Horo',314km West of Addis Ababa, the capital city of Ethiopia. The questionnaire was distributed in November and December 2019 (during harvest season) to sample of 250 from household farmers of Becho district and Horo district of equal representation. The questionnaire was designed to ask questions related to yield per hectare of farmland and farm cost of Teff and price of Teff at the farm gate. The farm costs asked and estimated by the farmers were on: labor cost, fertilizer, seed, production cost, transport cost to the collectors' site and other overhead costs during the five months of Teff production.

The results of the data were aggregated from the two locations to help determine the Teff production cost for the farmer. Based on the estimated costs, farmers were asked on the price they set adding transportation costs to the market using traditional transport systems like a mule, horse and donkey; or trucks and adding a profit margin on it. The standard unit to help calculate the Teff value chain is based on the costs incurred during production at farm site to consumption at consumer's site based on per Quintal (1Quintal=100kg) costs. Two Teff farm locations at Horo Woreda ((314 KM from Addis), and Becho-Ejere district (Becho area) were purposely selected as popular Teff production sites to analyze the Teff value chain and supply chain resilience in Ethiopia. Assuming farmers sell to consolidation centers (Farmers cooperatives), who will buy at farmers' price per quintal, collection sites at Shambu town (314 km from Addis Ababa) and Olankomi town (55 km from Addis Ababa) were considered as a second tier Teff value chain member to capture average daily price per quintal of Teff collection and the price at which they buy Teff including their profit margin when they resale it to wholesalers.

Two location owners/managers were interviewed and the average price of Teff per quintal was taken from the two sites separately. These Collectors are the ones who distribute to Addis Ababa wholesale market in a location commonly called 'IhilBerenda' or directly supply to retailers who own millhouses in Addis Ababa. To calculate the Teff value chain in the supply chain structure, on the third tier, five wholesalers at 'IhilBerenda' were considered for key informant interviews to calculate the average per quintal price of Teff they buy from collectors (framers cooperatives) and their profit margin per quintal. The last tier in the downstream Teff supply chain is the retailers at the millhouse who buy Teff from wholesalers and sell to Teff consumers (Addis Ababa residents). Assuming homogeneity and a large number of retail mills are uniformly available in the ten sub-cities of Addis Ababa, and two millhouses from Nefasilk Lafto Sub-city and Akakikaliti sub-city were randomly selected to conduct an interview with owners of two mill houses to help determine the average ultimate Teff price to consumers. Finally, value-added Teff transformed into baked bread known as 'Injera' producer, $20 \mathrm{~km}$ Southwest of Addis Ababa was interviewed on the quantity and price of 'Iinjera' per quintal after the value addition process by the firm. After data were captured from all actors of the Teff supply chain from farmers to retailers and 'Injera' producers, the ultimate consumers of Teff $(n=385)$ were randomly selected disproportionately from the two millhouses who randomly visited to buy Teff in January and February 2020. The question was raised to ask from the customer's perspective on how much Teff per quintal worth to buy it. Based on the collected data from primary sources at a different stage of the Teff supply chain including consumers, descriptive analysis was made. The Teff supply chain structure, as well as the value chain was determined. Based on the results of the data on the Teff value chain, the explanation was made on the problems in the Teff value chain and intervention strategies by the government to make the Agri supply chain in Ethiopia sustainable and resilient in the event of supply chain disruptions. 


\section{Data Analysis}

The analysis is made based on the surveyed data of Teff supply chain members from farmers to consumers on yield per hectare, teff supply chain costs, and gross profit margins for all supply chain members and value chain analysis from the consumer side. Lastly, value-added Teff into product is further analyzed in terms of gross profit margin and its implication.

Table 1. Farm Yield and Costs per hectare per Location(in Birr)

\begin{tabular}{lllll}
\hline Cost per hectare & Location & N & Mean & Std. Deviation \\
\hline Yield per hectare & Horo & 125 & 4.8480 & 1.33837 \\
& Becho & 125 & 4.7520 & 1.20252 \\
Fertilizer & Total & 250 & 4.8000 & 1.27061 \\
& Horo & 125 & 3248.0000 & 779.32974 \\
& Becho & 125 & 3224.0000 & 791.73146 \\
Plough & Total & 250 & 3236.0000 & 784.06827 \\
& Horo & 125 & 2092.0000 & 458.71489 \\
Weed & Becho & 125 & 2098.4000 & 467.48883 \\
& Total & 250 & 2095.2000 & 462.20286 \\
Harvest & Horo & 125 & 999.2000 & 293.06390 \\
& Becho & 125 & 1011.2000 & 280.32700 \\
Transport & Total & 250 & 1005.2000 & 286.25290 \\
& Horo & 125 & 1920.0000 & 246.83480 \\
& Becho & 125 & 1912.0000 & 247.27548 \\
& Total & 250 & 1916.0000 & 246.59122 \\
& Horo & 125 & 747.6000 & 154.87456 \\
& Becho & 125 & 744.0000 & 159.96471 \\
& Total & 250 & 745.8000 & 157.13410 \\
\hline
\end{tabular}

Source: Own survey, 2019

As depicted in Table 1, the average yield per hectare of Teff at Horo and Becho (mean 4.85, standard deviation 1.34; mean 4.75, standard deviation 1.2 respectively) are more or less the same with slightly higher at Horo. In general, this can be interpreted as low yield produce per hectare as compared to the average yield of teff in Ethiopia was 15.6 Quintal per hectare as indicated in the works of Cochrane and Bekele(2017). Regardless of its low yield per hectare, Teff produce is a staple food for the most Ethiopian food market.

The second variable is related to farm cost per location comprising fertilizer, plough, weeding, harvesting, and transportation costs. As a comparison, fertilize, harvest and transport costs per hectare are higher at Horo district with a mean of 3248, 1920 and 747.6 Birr (1 USD=33.5 Ethiopian Birr as of 21-04-2020) as compared to Becho with mean of 3224, 1912 and 744 Birr respectively. On the other hand, ploughing, and weeding costs are at Becho district with a mean of 2098, and 1011.2 Birr per hectare respectively as compared to Horo district's ploughing and weeding mean costs of 2092, and 999.2 Birr respectively.

Table 2. Average Farm Cost per hectare per Location (in Birr)

\begin{tabular}{lllll}
\hline Farm Cost & Location & $\mathrm{N}$ & Mean & Std. Deviation \\
\hline Average Farm Cost per hectare & Horo & 125 & 1801.3600 & 187.87583 \\
& Becho & 125 & 1797.9200 & 215.81539 \\
& Average & & 1799.6400 & 201.92913 \\
\hline
\end{tabular}

Source: Own survey, 2019

As shown in Table 2, the average farm cost in both locations is found to be around 1800 Ethiopian Birr with an insignificant higher cost at the Horo district. However, based on an interview made to triangulate the data from the selected farmers for farm cost data collection, labor cost which contributes significantly to the lion's share of farm cost was not properly accounted for in either of the two locations. Based on the market rate daily labor cost estimate, labor cost during farm season including accommodation and food expenses are not accounted for and therefore, grossly underestimated. This underestimation of labor cost at farm site which is a base for Teff value (price) calculation is a perceived cost than the actual cost of producing Teff per hectare per quintal. 
Table 3. Total Farm Cost per hectare by Location

\begin{tabular}{lllll}
\hline & Location & $\mathrm{N}$ & Mean & Std. Deviation \\
\hline Total Farm Cost & Horo & 125 & 9006.8000 & 939.37917 \\
& Becho & 125 & 8989.6000 & 1079.07697 \\
& Total cost & & 8998.2 & 1009.64563 \\
\hline
\end{tabular}

Source: Own survey, 2019

As portrayed in Table 3, overall farm production cost per hectare is on average close to 9000 Birr with a significant deviation from the average of around 1000 Birr. Noting the rationale given on the labor cost accounting grossly understated in the average cost calculation, the total cost of Teff production at the farm site will also be understated amount. Furthermore, Teff production in Ethiopia is made based on traditional farming with oxen, donkeys. Hence, lack of commercial- scale farming using mechanization regardless of the most popular and staple food item in Ethiopia, Teff remains at the hands of small scale household farming item with low yield per hectare of around five quintals. In Ethiopia, small-scale household farming is characterized by family labor to be deployed at farm sites for production from ploughing to harvest season with no accounting to the daily laborer activity costs related to farming. This will obviously underestimate the labor cost for a production cycle time of Teff during the five to six Months period. More specifically, Teff production season is from the beginning of July to the end of December.

Table 4. Consumer's Expected Price of Teff (in Ethiopian Birr per Quintal)

\begin{tabular}{llllll}
\hline & N & Minimum & Maximum & Mean & Std. Deviation \\
\hline Consumer's Expected Price of Teff per Quintal & 385 & 1500.00 & 4000.00 & 2412.7273 & 505.51036 \\
Valid N (listwise) & 385 & & & & \\
\hline
\end{tabular}

Source: Own survey, 2020

In Table 4, 385 randomly selected respondents were asked what first-grade Teff per quintal worth to them so that they are willing to pay to the retailer at millhouse and their expectations were on average 2413 Birr with a standard deviation of 506 Birr. As can be seen from the data, consumer's expectation of the price of Teff at the retail shop is based on the perceived low production cost of Teff at the farm site that led them to low price expectation, though the actual price of Teff is by far higher than their expected price as described in Table 5 .

Table 5. Teff Value Chain Cost and Price (in Ethiopian Birr per Quintal)

\begin{tabular}{llllllll}
\hline $\begin{array}{l}\text { Teff Supply } \\
\text { Chain } \\
\text { Member }\end{array}$ & $\begin{array}{l}\text { Average } \\
\text { Cost for } \\
\text { Farmer }\end{array}$ & $\begin{array}{l}\text { Farmer } \\
\text { Price }\end{array}$ & $\begin{array}{l}\text { Collector } \\
\text { Price }\end{array}$ & $\begin{array}{l}\text { Wholesale } \\
\text { r Price }\end{array}$ & $\begin{array}{l}\text { Retailer } \\
\text { Price }\end{array}$ & $\begin{array}{l}\text { Consumer's } \\
\text { Expected Price }\end{array}$ & $\begin{array}{l}\text { Value } \\
\text { added Teff } \\
\text { in to Injera }\end{array}$ \\
\hline $\begin{array}{l}\text { Average } \\
\begin{array}{l}\text { Cost/Price per } \\
\text { quintal }\end{array}\end{array}$ & 1800 & 2600 & 3200 & 3700 & 4200 & 2411 & 5600 \\
\hline
\end{tabular}

Source: Own survey, $2019 \& 2020$

As portrayed in Table 5, five actors in the Teff supply chain were identified as farmers, collectors, wholesalers and retailers before the commodity reaches the ultimate users (consumers) as the sixth supply chain member. Commodity brokers especially between collectors and wholesalers were excluded from the Teff supply chain analysis, as their value addition in information selling in this less complex agricultural commodity supply chain structure in Ethiopia was found to be insignificant.

Based on the presented data three-stage analyses were carried out. First, a cost-led pricing approach to Teff supply chain analysis was made. Accordingly, supply chain members from farmer to retailer accounted for their total supply chain cost in producing or reselling Teff added their profit margin to set a price and transacted to the next echelon of supply chain member until it reached the ultimate consumer of the product. Based on this, accepting the perceived cost of Teff production at farm site based on the available average farm costs per quintal, farmers gross profit margin was found to be $30.8 \%$, collector's profit margin was found to be $18.8 \%$, wholesaler's gross profit margin was $13.5 \%$, and retailer's gross profit margin was $11.9 \%$. Taking in to account the cost-led pricing approach, the profit margin for each supply chain member was found highest for the farmer and lowest for the retailer. However, based on the long production cycle of Teff at the farm site and unaccounted 
family labor cost for smallholder farmer which grossly underestimated the total farm cost per quintal, farmer's gross profit margin for Teff were diminutive. On the contrary, the remaining supply chain members: collectors, wholesalers and retailers relatively enjoyed above theoretical profit margin with relatively quick inventory turnover with no intrinsic value addition on the Teff commodity that is produced by the farmer.

Second, Teff value chain analysis was made based on the sample respondent of ultimate users of Teff at Addis Ababa city depending on the price of Teff from the consumers' view on what the product worth to pay for it per quintal. Accordingly, their expectation was far below the average price of Teff at the retail shop, with a mean value of 2411 Birr. Customers are willing to pay a maximum of 2411 Birr for first grade Teff at retail millhouses, where the actual price was 4200 . The Teff supply chain price (Birr 4200) and Teff value chain price (Birr 2411) had a gap of almost the cost of producing commodity Teff per quintal, which is 1800 Birr. The anomaly is that the total farm cost of Teff is grossly underestimated due to unaccounted family labor cost, traditional farming system and lack of mechanization and as a result of low yield of Teff produce per hectare. On the contrary, consumers on the other end of the Teff supply chain have high expectation of Teff price to be low priced of 2411 Birr only. The three Teff supply chain intermediaries (collectors, wholesalers and retailers) have enjoyed relatively good profit margin without intrinsic value addition to the Teff commodity beyond reselling.

Third, after Teff's commodity value chain analysis at the consumer level, further value-added analysis of Teff was made when manufacturers transformed into the branded product by making baked bread commonly known as 'Injera' in Ethiopia. Accordingly, based on the data obtained from a manufacturer of Injera, on average per quintal Teff can be value-added into 700 units of 'Injera' with an average retail price of 8 birr per unit. Excluding operational expenses of making Injera at the Injera manufacturing site, the company enjoys a gross profit margin of $33.9 \%$, assuming Injera manufacturers directly buy from wholesalers. The gross margin is even higher (42.9\%), as there is a possibility for the Injera manufacturer to buy Teff commodity directly from collectors at farm site. This implies that the more value is added to agricultural products across the downstream supply chain member, the more gross profit margin is obtained that leads to more wealth creation at the downstream Teff supply chain member than farmers of Ethiopia.

In another study made by (Alexandre et al., 2018) identified fires at distribution centers, tsunami and floods leading to production facility disruptions, legal conflicts between suppliers, and strikes at airlines and railway companies cause the ripple effect. To ensure sustainable food supply in developing countries like Ethiopia, supply chain disruptions like COVID 19 and its ripple effect should be mitigated by creating a developed agricultural supply chain by enabling farmers to produce surplus agricultural products through government intervention of subsidy and hedge. However, as can be observed from one of the essential agricultural commodities in Ethiopia, Teff, and its supply chain structure at the commodity level passes through different echelons without intrinsic value addition until it reaches the consumer. Those manufacturers who add value to Teff into the branded product by making Injera enjoyed a higher gross profit margin as compared to the original commodity producer, the farmer. Hence, the Teff supply chain analysis which is based on cost-led pricing from farm gate price to retail price resulted in creating more wealth to the retailers than to the farmers. As more wealth is accumulated in the downstream Teff supply chain members and gross underestimation of agricultural costs due to family farming at the household level, it is highly unlikely to create more wealth at upstream supply chain members (farmers) by saving from the profit margin of Teff. On the other hand, the Teff value chain (the price of Teff from the consumers' side) was found to very low. To avail Teff commodity to consumers as per the expected price of the consumers necessitates the removal of middle supply chain members from collector to the retailer. This implies the direct channel of the farmer to consumer supply of Teff.

Therefore, Ethiopia's essential commodity supply chain structure like Teff remains anomaly as it is an underpriced item at the farm gate and yet low price expectation at the consumer site. As a result, resilient Teff supply chain creation in Ethiopia is a long way to go even under normal course of operation than supply chain disruption like the COVID 19 case. So, the aforementioned analysis tells us there needs government intervention supported with conducive policy framework through structural transformation of the sector from its current mode of operation in all aspects. Consequently, to create a resilient supply chain in the event of supply chain disruption like COVID 19. This is possible among many factors based on two government interventions through subsidy and hedging to farmers in Ethiopia.

\section{Conclusions}

Depending on the context and the effect of the pandemic, each country must realize the severity of the situation and sometimes should tighten or loosen the measures according to the spread of the pandemic. The supply chain should also be flexible enough to respond to the challenges in the food supply chain. The ability of developing 
countries like Ethiopia to recover quickly from shocks and the flexibility of the supply chain system; to weather variations caused by an unprecedented crisis such as COVID-19 requires developed agriculture and well-functioning supply chain members. This necessitates agricultural mechanization, support of farmers, through direct subsidy and hedging by the government to enable them to accumulate wealth to re-invest and produce more to keep enough stocks in the case of supply disruptions caused by events like COVID 19.

However, Teff supply chain creation in Ethiopia is a long way to go even under normal course of operation than supply chain disruption like the COVID 19. This is due to agricultural supply chain structural problem created as a result of under-costing of agricultural produce like Teff, low yield per hectare, low gross profit margin at upstream supply chain member, and high profit-margin for retailers without intrinsic value addition, and also high-profit margin after value addition of Teff into manufactured consumable goods. As a result, farmers are not enjoying high-profit margins that worth their effort due to: long production cycle time(five Months), high agricultural inputs' cost, free family labor cost, low yield per hectare, and risk of bad weather and price fluctuation. As a result, it is not enough for the farmer to cover the cost of production and generate enough income for saving that result in wealth creation. Hence, Teff producers cannot go beyond the teff value chain of subsistence to saving and then investment. In addition, from the teff value chain analysis, consumers at Addis Ababa have low price expectations on the quality grade of Teff regardless of its current actual price at the retail shop, which is perceived as higher during COVID 19. On the other hand, wholesalers and retailers are enjoying a relatively higher profit margin on the Teff commodity price without changing any intrinsic value of teff produce at farmers' sites. The downstream Teff supply chain members (wholesalers and retailers) also benefited from the consolidation effect from different Teff commodity suppliers from farm sites, short cash to cash cycle time, and price increase during COVID 19, due to supply chain disruptions caused by lockdown policy. Hence the purpose of this review is to evaluate the impact of COVID-19 on the agriculture and food sector and to summarize the recommendations required to reduce and control the effect of the pandemic.

\section{Recommendations}

Based on the findings of the data analysis, the following recommendations demand government intervention to avoid disruptions of essential commodities like Teff during COVID 19 and other extra ordinary events. Therefore, the government should facilitate the movement of workers and agri-food products. In addition, small farmers or vulnerable people should be supported financially. Facilities should change the working conditions and maintain the health and safety of employees by altering safety measures. Food protectionist policies should be avoided to prevent an increase in food prices. This is possible by taking a combination of measures aimed at ensuring governing agricultural supply chain in a way essential commodity supply like Teff to the market is not disrupted during COVID 19. This can start by enlarging subsidies for Ethiopian farmers to boost agricultural production. Through this fund, improved seed and fertilizer can be distributed at a lower price than the status quo. Furthermore, additional measures that can be taken by the government is to hedge farmers against price fluctuation, market volatility and insuring against natural and human-made risks of their crops.

The hedging will also give farmers the confidence to produce more as the government will buy their product at a fixed price which is a competitive price for farmers to sell and make a profit, without any risk of loss. This will be critical as price fluctuations in agricultural inputs hamper sustainable production by farmers. The government would also need to avail warehouses for stocking agricultural commodities to buffer against future uncertainties, just in case COVID-19 continues to spread beyond one production season. The government can buy it from the farmers at a fixed or market price and stock it in warehouses, a move that would also address, to an extent, the market problem for agricultural products and also hedge farmers against price fluctuation due to over-production than the market needs. To complement these measures, Maximum Retail Prices (MRP) should be set for essential commodities such as Teff, at each stage of the supply chain and regulated based on cost-led pricing. This could be optimized by allocating supply chain profit sharing based on the theoretical profit margins created along the supply chain members based on the value that is added to the agricultural product until it reaches the final consumer. Obviously, the first intrinsic value adder on Teff commodity should enjoy a higher profit margin by truly accounting the family costs into farm costs. Such price setting should be regulated by the government through commodity tracking systems from farm gates to retail millhouses.

\section{Acknowledgments}

The author would like to acknowledge the valuable inputs from the anonymous reviewers.

\section{Conflicts of Interest}

The author declares there is no conflict of interest with regard to this study, research findings with any party. 


\section{Funding information}

This research received no specific grant from any funding agency in the public, commercial or nonprofit sectors.

\section{Disclaimer}

The views and opinions expressed in this article are those of the author and do not necessarily reflect the official policy or position of any affiliated agency of the authors.

\section{Data Availability Statement}

Primary Data gathered from research participants will be available up on request.

\section{References}

Aday, S. (2020). Impact of COVID-19 on the food supply chain. Food Processing Department, Vocational School of Biga, Canakkale Onsekiz Mart University, Biga, Canakkale, Turkey.

Bakalis, S., Valdramidis, V. P., Argyropoulos, D., Ahrnee, L., Chen, J., Cullen, P. J., ... Van Imper, J. F. M. (2020). Perspectives from CO+RE: how COVID-19 changed our food systems and food security paradigms. Current Research in Food Science, 3, 166-172. https://doi.org/10.1016/j.crfs.2020.05.003

Chandrasekaran, N., \& Raghuram, G. (2014). Agribusiness Supply Chain Management. CRC Press. Boca Raton, Florida. https://doi.org/10.1201/b16704

Cochrane, L., \& Bekele, Y. W. (2017). Average Crop Yield (2001-2017) in Ethiopia: Trends at national, regional and zonal levels. Data in Brief, 16, 1025-1033. https://doi.org/10.1016/j.dib.2017.12.039

Cranfield, J. A. L. (2020). Framing consumer food demand responses in a viral pandemic. Canadian Agricultural Economics Society, 68, 151-156. https://doi.org/10.1111/cjag.12246

Devereux, S., Bene, C., \& Hoddinott, J. (2020). Conceptualising COVID-19's impacts on household food security. Food Security, 12, 769-772. https://doi.org/10.1007/s12571-020-01085-0

FAO. (2020). Food and Agriculture Organization. Q\&A: COVID-19 Pandemic - Impact on Food and Agriculture. Retrieved from http://www.fao.org/2019-ncov/q-and-a/en/

Flynn, D. (2020). CDC provides first guidance to a specific meat plant for combating COVID-19 among employees. Retrieved from https://www.foodsafetynews.com/2020/04/cdc-provides-first-guidance-to-a-specificmeat-plant-for-combati ng-covid-19-among-employees

Govindan, K., Mina, H., \& Alavi, B. (2020). A Decision Support System for Demand Manag ment in Healthcare Supply Chains Considering the Epidemic Outbreaks: A Case Study of Cor navirus Disease 2019 (COVID-19). Transportation Research Part E: Logistics and Transportation Review, 138, 101967. https://doi.org/10.1016/j.tre.2020.101967

Hey, J. (2020). Coronavirus: Measuring the Market Impact. In Fruitnet. London. Retrieved from https://www.fruitnet.com/asiafruit/article/181021/coronavirus-measuring-the-market-impact

IMF. (2020). Policy responses to Covid-19. Washington, DC: International Monetary Fund. Retrieved from https://www.imf.org/en/Topics/imf-and-covid19/Policy-Responses-to-COVID-19\#I

Ivanov, D. (2020a). Predicting the Impacts of Epidemic Outbreaks on Global Supply Chains: A Simulation-Based Analysis on the Coronavirus Outbreak (COVID-19/SARS-CoV-2) Case. Transportation Research Part E: Logistics and Transportation Review, 136, 101922. https://doi.org/10.1016/j.tre.2020.101922

Mahajan, K., \& Tomar, S. (2020). COVID-19 and Supply Chain Disruption: Evidence from Food Markets in India. Amer. J. Agr. Econ., 103(1), 35-52. https://doi.org/10.1111/ajae.12158

Mirgissa, K., \&Yayehyirad, K. (2020). Novel coronavirus (2019-nCoV) - reminiscent of Spanish flu: A challenge to global public health systems. Ethiopian Journal of Health Development, 34(1).

Parker, R., \& Stewart, J. (2014). Energy and Food Security Is Australia Fragile or Resilient?

Popopo, M. (2020). Analysis of the Impact of COVID-19 on the Food and Beverages Manufacturing Sector. Food and Beverage Manufacturing Sector Education and Training Authority, Johannesburg 2006, Gauteng, South Africa.

Sharma, R., Shishodia, A., Kamble, S., Gunasekaran, A., \& Belhadi, A. (2020). Agriculture supply chain risks and COVID-19: mitigation strategies and implications for the practitioners. International Journal of 
Logistics Research and Applications. https://doi.org/10.1080/13675567.2020.1830049

Siche, R. (2020). What is the Impact of COVID-19 Disease on Agriculture?. Scientia Agropecuaria, 11(1), 3-6. https://doi.org/10.17268/sci.agropecu.2020.01.00

Telukdarie, A., Munsamy, M., \& Mohlala, P. (2020). Analysis of the Impact of COVID-19 on the Food and Beverages Manufacturing Sector. Sustainability, 12(22), 9331. https://doi.org/10.3390/su12229331

Tsolakis, N. K., Keramydas, C. A., Toka, A. K., Aidonis, D. A., \& Iakovou, E. T. (2014). Agrifood Supply Chain Management: A Comprehensive Hierarchical Decisionmaking Framework and a Critical Taxonomy. Biosystems Engineering, 120, 47-64. https://doi.org/10.1016/j.biosystemseng.2013.10.014

WFP (World Food Programme). (2020a). COVID-19 will double number of people facing food crises unless swift action is taken. Retrieved from

https://www.wfp.org/news/covid-19-will-double-number-people-facing-foodcrises-unless-swift-action-taken

\section{Copyrights}

Copyright for this article is retained by the author(s), with first publication rights granted to the journal.

This is an open-access article distributed under the terms and conditions of the Creative Commons Attribution license (http://creativecommons.org/licenses/by/3.0/). 